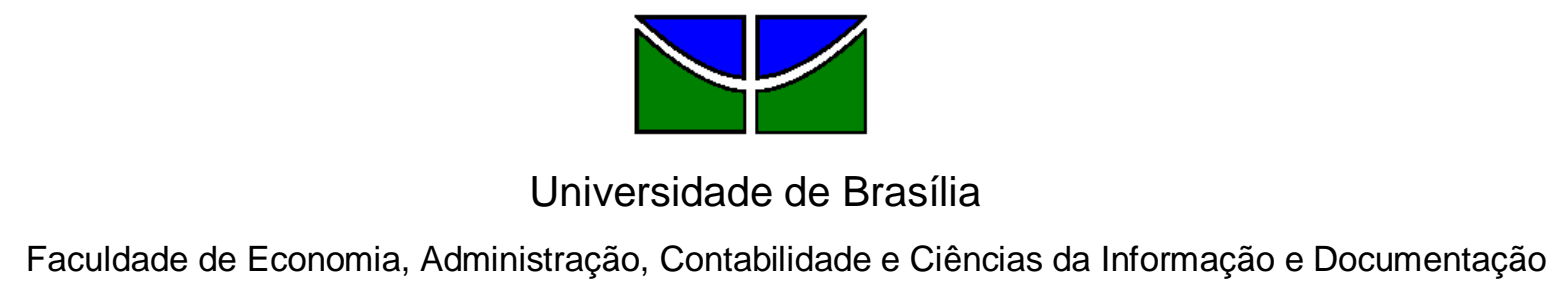

Departamento de Administração

GENIVALDO DE FREITAS BONFIM

\title{
A REESTRUTURAÇÃO DA CARREIRA DE ESPECIALISTA EM POLÍTICAS PÚBLICAS E GESTÃO GOVERNAMENTAL E SEU IMPACTO NA REFORMA ADMINISTRATIVA DE 1995
}

Brasília - DF

2010 


\title{
A REESTRUTURAÇÃO DA CARREIRA DE ESPECIALISTA EM POLÍTICAS PÚBLICAS E GESTÃO GOVERNAMENTAL E SEU IMPACTO NA REFORMA ADMINISTRATIVA DE 1995
}

Monografia apresentada ao Departamento de Administração como requisito parcial para obtenção do grau de Bacharel em Administração.

\author{
Professor Orientador \\ José Matias Pereira, Dr.
}

Professor Co-orientador

Marcos Ozório de Almeida, Esp.

Brasília - DF

Dezembro/2010 
Bonfim, Genivaldo de Freitas.

A Reestruturação da Carreira de Especialista em Políticas Publicas e Gestão Governamental e seu Impacto na Reforma Administrativa de 1995/ Genivaldo de Freitas Bonfim. - Brasília, 2009. 43 f.: il.

Monografia (bacharelado) - Universidade de Brasília, Departamento de Administração - EaD, 2010.

Orientador: Prof. Dr. José Matias Pereira, Departamento de Administração.

Co-orientador: Prof. Esp. Marcos Ozório de Almeida

1. Reforma Administrativa de 1995. 2. Fortalecimento do Núcleo Estratégico. 3. Reestruturação da Carreira de EPPGG. 
GENIVALDO DE FREITAS BONFIM

\title{
A REESTRUTURAÇÃO DA CARREIRA DE ESPECIALISTA EM POLÍTICAS PÚBLICAS E GESTÃO GOVERNAMENTAL E SEU IMPACTO NA REFORMA ADMINISTRATIVA DE 1995
}

\begin{abstract}
A Comissão Examinadora, abaixo identificada, aprova o Trabalho de Conclusão do Curso de Administração da Universidade de Brasília do aluno
\end{abstract}

\section{Genivaldo de Freitas Bonfim}

José Matias Pereira, Dr.

Professor Orientador
Marcos Ozório de Almeida, Esp.

Professor Co-orientador

Josias Rodrigues Alves, Esp.

Professor-Examinador 
Este trabalho é dedicado àqueles que diretamente tiveram participação no seu desenvolvimento: Dr. José Matias Pereira, Esp. Marcos Ózorio de Almeida e minha família. 


\section{AGRADECIMENTOS}

Por este feliz momento, agradeço, em especial a Deus, ao Governo Federal do Brasil, na figura do Presidente Luis Inácio da Silva, pela criação da Universidade Aberta do Brasil, à Universidade de Brasília que abraçou esse projeto, aos distintos professores e servidores pela dedicação ao trabalho realizado.

Agradecimentos sinceros ao professor-supervisor Dr. José Matias Pereira, um apaixonado pelo projeto do curso a distância e grande incentivador dos alunos, ao professor-tutor Espec. Marcos Ozório de Almeida pela dedicação e generosidade e por ter acreditado no meu compromisso de realizar esse trabalho nesse semestre.

Também agradeço a valiosa colaboração dos entrevistados: Maria da Penha B. da Cruz (MPOG), Sandro Eli M. de Alencar (MPOG) e Ciro Campos C. Fernandes (MPOG).

Chegar ao final desse trabalho é a conclusão de uma caminhada que começou há nove semestres. Dificuldades existiram, mas as lembranças que ficam são das superações.

Conseguir fazer esse curso, superando várias dificuldades é fruto da influência de várias pessoas: meus pais, Osvaldo e Raimunda, que me ensinaram que conhecimento é a maior herança que um pai pode deixar a um filho; meus filhos, Emanuel e Isabela parte especial da razão porque luto; minha esposa, Elisete, companheira incondicional de todas as horas e meu presente de Deus. A todos, meus agradecimentos mais distintos.

Obrigado aos meus familiares e amigos pela compreensão em muitas ausências do seu convívio, motivadas pela realização desse projeto. Em especial a minha amiga, Maria Aparecida, uma apaixonada pela Administração e que sempre me incentivou a cursar essa cadeira.

Terminei! 


\section{RESUMO}

As reformas administrativas brasileiras sempre foram uma forma de tentar aprimorar a gestão pública em nosso país, mas é verdade também que inúmeras vezes elas foram usadas como plataforma eleitoral ou retórica em esboços de programas de Governo. Podemos considerar como a primeira dessas reformas a realizada na década de 1930 pelo Governo de Getúlio Vargas que reduziu bastante as práticas patrimonialistas de gerir o Estado. Posteriormente tivemos, sem muito sucesso, a tentativa de reforma implantada através edição do Decreto-Lei 200 de 1967, durante os governos militares. Com a redemocratização, tentou-se uma reforma no Governo Sarney, da qual resultou como pontos positivos a criação da Escola Nacional de Administração Pública e a criação da Carreira de Especialista em Políticas Públicas e Gestão Governamental (EPPGG). No Governo Collor tentou-se fazer nova reforma administrativa, que não logrou êxito. Já no Governo Fernando Henrique Cardoso, o Ministro Bresser Pereira foi responsável, a partir de 1995, por implementar uma nova e grande reforma administrativa no Brasil. Um dos objetivos dessa Reforma era o fortalecimento do Núcleo Estratégico do Estado; para realizar essa tarefa, Bresser Pereira optou por fortalecer as carreiras do chamado Ciclo de Gestão do Estado, nesse processo ela realizou uma grande reestruturação da carreira de EPPGG. Essa reestruturação trouxe para o Núcleo Estratégico do Estado um corpo de servidores bem treinados e sintonizados com as propostas de gestão previstas na Reforma. Esses profissionais tiveram uma participação marcante nas mudanças ocorridas na gestão da Administração Pública durante os dois Governos de Fernando Henrique, participando de vários projetos e ocupando vários Cargos de Direção em todos os níveis na Administração Pública. O trabalho de sucesso desses profissionais continuou nos dois mandatos seguintes do Presidente Lula. Na construção dessa pesquisa foram utilizados vários estudos, livros, artigos e entrevistas que levaram à conclusão que a reestruturação da Carreira de EPPGG foi um instrumento eficaz para que a Reforma Administrativa de 1995 tivesse sucesso no objetivo de fortalecer o Núcleo Estratégico do Estado.

Palavras chave: Reforma Administrativa, Núcleo Estratégico, Carreira de EPPGG. 


\begin{abstract}
The Brazilian administrative reforms have always tried to refine the Public Administration in our country. But, it is also true that a lot of times they were used as election platforms or rhetoric in rough drafts of government programs. One may consider as the first reform achieved in the 1930's by the Vargas Government, which reduced the lack of distinction between public and private in the public sector administration. Later, there was another somewhat unsuccessful reform that was implemented through the edition of Decree-law 200 from 1967, during the course of the military governments. With the re-democratization, there was an effort in Sarney's Government that resulted in positive points, like the creation of the National School of Public Administration and the EPPGG career (Portuguese acronym for Government Manage and Public Policies Specialist). Afterwards, another administrative reform came off badly during the Collor Presidency. In Fernando Henrique Cardoso's Government, as of 1995, Minister Bresser Pereira was responsible to establish a new and great administrative reform in Brazil. One of this reform's objectives was strengthening the State' Strategic Nucleus. To put this into practice, Bresser Pereira opted to strengthen the careers from the so-called State's Cycle of Management. In this process, he accomplished a great restructuring of the EPPGG career. This restructuring brought to Strategic Nucleus a well trained corps of servants, which was synchronized with the reforms proposals. These professionals had a remarkable participation in changes that took place in public administration management during the two Cardoso governments. They participated in several projects and engaged in a lot of managerial functions at all administration levels. These professionals' successful work continued in the two mandates of President Lula. On this research, a lot of studies, books, articles and interviews were used. The conclusion is that the restructuring of the EPPGG career was an effective instrument for the Administrative Reform of 1995 and to the success in objective of strengthening the State' Strategic Nucleus.
\end{abstract}

Key-words: Administrative reform. Strategic Nucleus. EPPGG career. 


\section{SUMÁRIO}

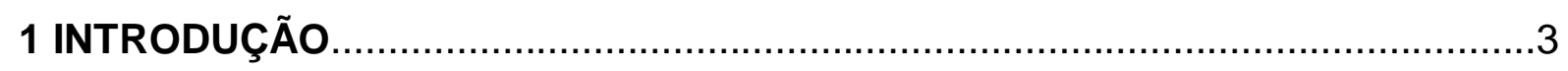

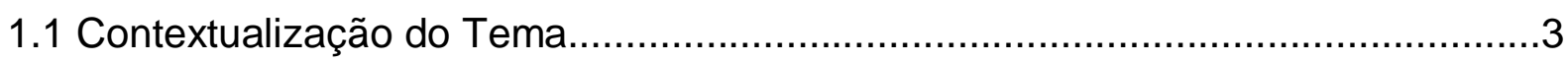

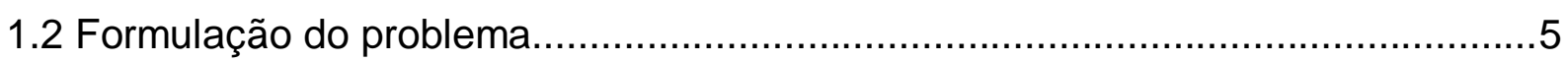

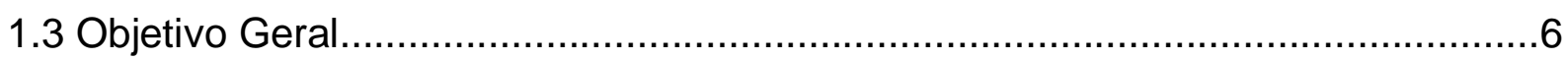

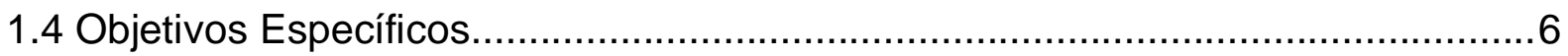

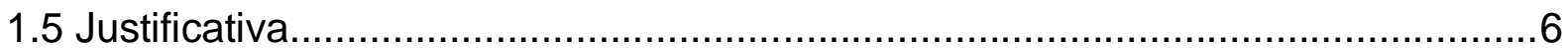

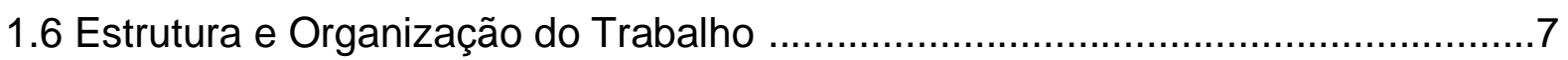

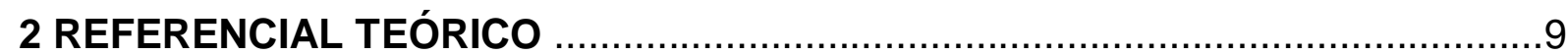

2.1 Relato Histórico das Reformas Administrativas Brasileiras.................................

2.2 Análise Comparativa das Reformas Administrativas Brasileiras .......................11

2.3 Os Motivos do Fracasso das Reformas Administrativas ..................................15

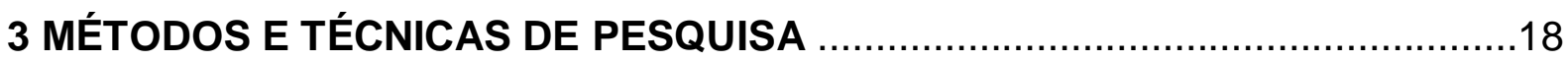

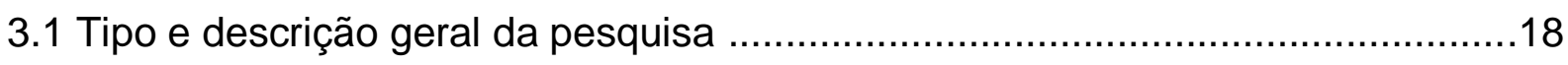

3.2 Caracterização da organização, setor ou área...............................................19

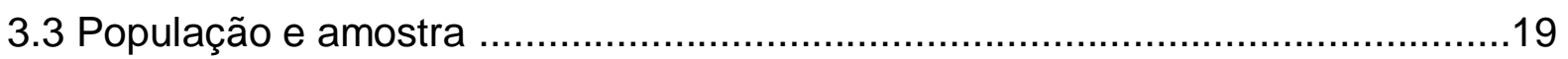

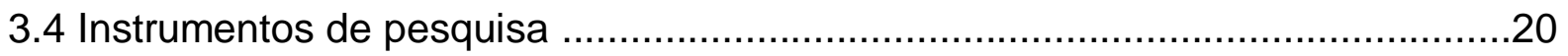

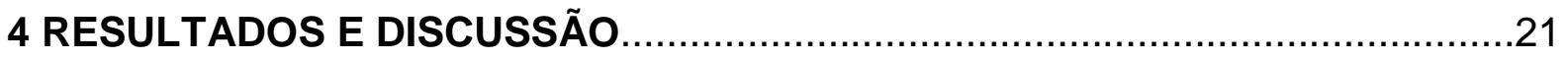

4.1 A Carreira de EPPGG antes da Reforma Administrativa de 1995 ....................21

4.2 A eficácia da reestruturação da carreira de EPPGG para o fortalecimento do

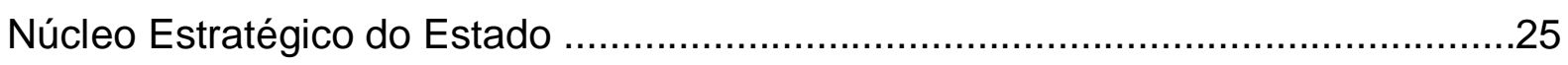

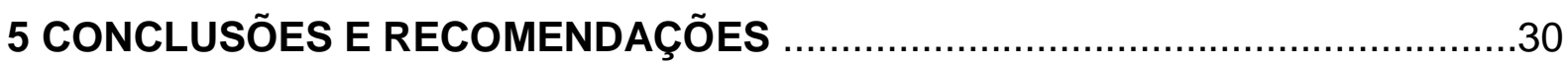

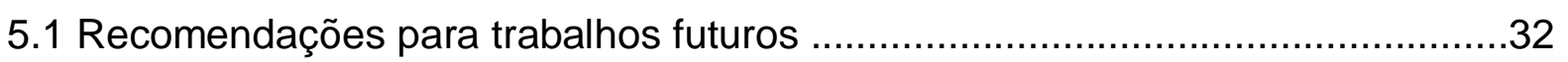

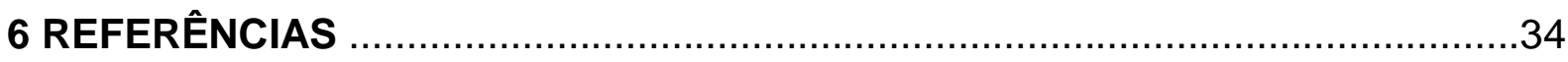

7 APÊNDICES

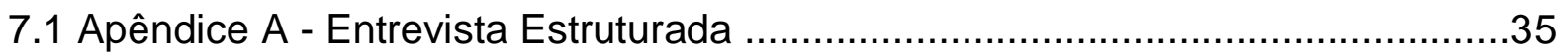

7.2 Apêndice B - TERMO DE CONSENTIMENTO LIVRE E ESCLARECIDO ..........36

7.3 Apêndice C - Entrevista: Maria da Penha B. da Cruz - Coordenadora-Geral da Gestão da Carreira de EPPGG do Ministério do Planej. Orçamento e Gestão 
7.4 Apêndice D - Entrevista: Sandro E. M. de Alencar - Coordenador da Coordenação-Geral da Gestão da Carreira de EPPPG do Ministério do Planej.

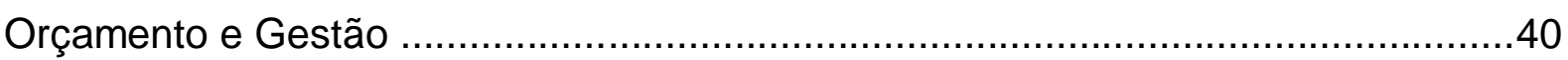
7.5 Apêndice E - Entrevista: Ciro C. C. Fernandes - Diretor de Articulação e Inovação Institucional do Ministério do Planej. Orçamento e Gestão 42 


\section{INTRODUÇÃO}

\subsection{Contextualização do Tema}

As reformas na administração pública brasileira vêm sendo realizadas, de forma mais efetiva, desde a década de 1930. Diversos foram os motivos e circunstâncias que impulsionaram essas reformas: busca de modernização da administração, melhoria nos serviços públicos e outros; já dentre as circunstâncias, encontramos: revoluções, conjunturas econômicas e quadros político-eleitorais.

A história dessas reformas se confunde com a própria história do país, e acompanha uma seqüência cronológica na qual o Estado busca adaptar sua administração à realidade político-econômica vigente. Mas, sempre seguindo uma tendência mundial de mudanças e evoluções nas administrações públicas, na maioria das vezes, é verdade, com um lapso temporal grande, entre os acontecimentos nos países de vanguarda e a implementação das novas idéias em nossas terras. Ressalvas feitas ao Decreto 200 de 1967, que representava uma mudança na nossa administração pública, incorporando práticas administrativas que, somente a partir da década de 1980, seriam difundidas nos países desenvolvidos como práticas de um modelo gerencial de administração.

O tema suscita muitas discussões devido às colorações ideológicas que sempre tiveram por trás dessas Reformas no Brasil, embora as diversas reformas da administração pública, tanto no Brasil, como em outros países, não remetam a uma ruptura com o modelo anterior vigente e, nenhuma delas tenha conseguido livrar-se completamente da influência do modelo burocrático desenvolvido por Max Weber. No Brasil, elas sempre representaram uma disputa ideológica entre as correntes políticas que defendem práticas mais liberais de gestão do Estado e redução da participação deste na economia, e àquelas que defendem um modelo de estado mais estatizante e interventor. Com um grupo sempre alegando que o outro está completamente errado; afirmando ser a Reforma que empreenderá um rompimento com o modelo defendido pelos seus opositores. Quando na verdade as reformas administrativas deveriam ser defendidas sob o argumento da modernização da 
máquina pública e da prestação de serviços públicos de alta qualidade, independente do modelo de Estado que o Governo de plantão defenda.

A Reforma Administrativa de 1995, da qual trataremos nesse trabalho, de modo mais específico, diferencia-se das demais tentativas de reformas implementadas no Brasil entre 1930 e 1995. Essa Reforma foi apresentada à sociedade como uma quebra de paradigma, uma mudança no modelo de gestão pública, uma evolução do modelo burocrático de gerenciar o estado (gestão autoreferenciada) para o modelo gerencial (gestão voltada para os resultados).

A respeito do tema, Bresser Pereira, em artigo publicado na Revista de Administração Pública em 2000, disse o seguinte.

\begin{abstract}
Prefiro falar em uma Reforma Gerencial do Estado, e, portanto, que a transição do Estado Produtor para o Estado Gerencial, que vai além de criar agências reguladoras: é também o Estado democrático e eficiente, que financia a fundo perdido os serviços sociais e de pesquisa científica, e age como capacitador (enabler) da competitividade das empresas privadas. (BRESSER PEREIRA, 2000, p.2).
\end{abstract}

Independente das críticas ou elogios tecidos a respeito dessa Reforma, precisamos admitir que existe uma diferença entre ela e as outras que lhe antecederam entre 1930 e 1995. Todas as outras Reformas anteriores tiveram como objetivo aprimorar processos administrativos definidos na Reforma Burocrática de 1930. A Reforma de 1995 se propõe a fazer uma nova abordagem da gestão pública brasileira, centrada em três pilares: cultural (visava despertar no servidor público uma nova mentalidade, voltada ao atendimento ao cidadão, passando do modelo burocrático ao gerencial); institucional (que propunha reformas nas leis, para alterar relações de emprego dos servidores públicos e criar instituições novas, tais como, agências executivas e organizações sociais); por último, o pilar gestão, que é a parte mais visível da reforma, é a aplicação prática do que foi definido nos outros dois pilares, com o objetivo de prestar um serviço público de melhor qualidade.

Por se tratar de um tema dinâmico e atual, em constante processo de evolução e com muita conectividade com a vida dos cidadãos, é que foi abordado nesse trabalho de conclusão de curso; em busca de responder à seguinte questão de pesquisa: pela perspectiva da reestruturação da carreira de Especialista em Políticas Públicas e Gestão Governamental, a Reforma Administrativa de 1995 obteve sucesso no objetivo de fortalecer o núcleo estratégico do Estado? 


\subsection{Situação Problema}

A Reforma Administrativa de 1995 propôs levar a administração pública brasileira do modelo burocrático ao gerencial. Para tanto ela foi estruturada em três dimensões: institucional, cultural e gestão.

Analisando a dimensão da gestão, verificamos que a concepção de estado moderno, definido no projeto da Reforma Administrativa de 1995, pressupõe a existência de três setores: as atividades exclusivas do Estado, do qual faz parte o Núcleo Estratégico (integrado pelos Chefes dos Três Poderes e Primeiro Escalão de servidores de cada um deles e o Ministério Público; além dos servidores bem preparados destinados a assumir cargos de assessoramento dos níveis citados anteriormente); os serviços sociais e científicos e o setor de produção de bens para o mercado.

Uma das principais estratégias dessa Reforma, na dimensão gestão, foi o fortalecimento do Núcleo Estratégico do Estado. Através da sua ocupação por servidores públicos competentes, bem treinados e bem remunerados; imbuídos do novo espírito do serviço público, proposto pela reforma: servir bem ao cidadão.

Dentro dessa estratégia previa-se também a alocação dessa elite de servidores em carreiras estáveis e previstas em lei. Porque nessa Reforma ficou entendido que, nas atividades exclusivas de Estado, a efetividade é, quase sempre, mais relevante que a eficiência.

Sintetizando, a Reforma Administrativa de 1995, dentro da dimensão gestão, propunha o fortalecimento do Núcleo Estratégico do Estado. Através da valorização e preparação dos servidores que integrariam esse núcleo; fortalecendo suas carreiras, garantindo-lhes estabilidade e remunerando-os bem. Diante desse contexto o questionamento que esse trabalho se propõe a responder é: pela perspectiva da reestruturação da carreira de Especialista em Políticas Públicas e Gestão Governamental, a Reforma Administrativa de 1995 obteve sucesso no objetivo de fortalecer o Núcleo Estratégico do Estado? 


\subsection{Objetivo Geral}

Analisar a reestruturação da carreira de Especialista em Políticas Públicas e Gestão Governamental implementada pela Reforma Administrativa de 1995. Com a finalidade de comprovar se essa reforma atingiu um dos objetivos a que se propôs: fortalecer o núcleo estratégico do Estado e ocupá-lo com servidores públicos de alta competência, bem treinados e remunerados.

\subsection{Objetivos Específicos}

Apresentar uma análise histórica das Reformas Administrativas brasileiras, comparando seus pontos positivos e negativos.

Analisar a situação em que se encontrava a carreira de Especialista em Políticas Públicas e Gestão Governamental, antes da implantação da Reforma Administrativa de 1995.

Avaliar a reestruturação ocorrida, a partir de 1995, na carreira de Especialista em Políticas Públicas e Gestão Governamental, para comprovar se ela foi uma ferramenta eficaz para atingir o objetivo de fortalecer o Núcleo Estratégico do Estado, como previa a Reforma Administrativa de 1995.

\subsection{Justificativa}

As reformas administrativas são objeto de ampla discussão, na maioria das vezes, em nosso país, contaminadas pela orientação ideológica, tanto dos críticos, quanto dos seus defensores.

Realizar um estudo sobre uma reforma administrativa, de maneira independente, ao menos buscando essa independência, abstraindo-se das influências ideológicas, é uma boa oportunidade de avaliar melhor os seus aspectos técnicos. Buscando conhecer os fundamentos reais que a motivaram, os objetivos que se pretendeu atingir com ela, os ganhos que trouxera para a sociedade e 
comparar o custo benefício de implantar uma Reforma Administrativa ou manter o sistema de gestão já implantado.

A Reforma Administrativa de 1995 tinha, na sua proposta, grandes mudanças na administração pública brasileira. Alterações na legislação, criação de instituições, quebra de paradigmas, rupturas de situações trabalhistas há muito estabelecidas, além exigir dos servidores públicos uma mudança radical de cultura.

Pela amplitude dessa reforma fica fácil perceber que avaliá-la por completo seria uma tarefa impossível de se realizar, ao menos num trabalho de curso em nível de graduação. Assim, a justificativa do presente trabalho está na possibilidade de avaliar se os efeitos da Reforma sobre a gestão pública foram positivos ou negativos; a partir da análise, isolada, de um fato (reestruturação da carreira de Especialista em Políticas Públicas e Gestão Governamental) que está diretamente ligado a um dos objetivos da Reforma (fortalecimento do Núcleo Estratégico do Estado, a partir da ocupação desse núcleo por servidores públicos bem preparados).

\subsection{Estrutura e Organização do Trabalho}

Esse trabalho apresenta a seguinte estrutura: o primeiro capítulo é composto pela introdução para contextualização do tema, formulação da situação problema, apresentação dos objetivos do trabalho, justificativa da pesquisa e a estrutura e organização do trabalho.

O segundo capítulo é dedicado à discussão do referencial teórico que se compõe de um relato histórico das Reformas Administrativas brasileiras segundo Frederico Lustosa da Costa (2008); seguido de uma análise dessas Reformas no período que compreende entre 1930 e 1995, por Luiz Carlos Bresser Pereira (1996); finalizando com uma explanação do trabalho de Flávio da Cunha Rezende (2004), onde ele explica porque as reformas administrativas, de modo geral, fracassam.

No terceiro capítulo são abordados os métodos e técnicas de pesquisa utilizada na construção deste estudo.

O quarto capítulo dedica-se aos resultados da discussão e está subdividido em duas partes: a primeira faz uma análise da situação em que se encontrava a carreira de Especialista em Políticas Públicas e Gestão Governamental (EPPGG) 
antes da Reforma Administrativa de 1995; enquanto a segunda faz uma avaliação da reestruturação da carreira de EPPGG ocorrida a partir de 1995, para verificar se ela atendeu ao objetivo de fortalecer o Núcleo Estratégico do Estado, previsto na referida Reforma.

O quinto capítulo traz a conclusão, onde são apresentadas as opiniões formadas a partir da análise dos capítulos anteriores.

Finalizando, são apresentadas as referências bibliográficas utilizadas na elaboração do presente trabalho, bem como apêndices e anexos. 


\section{REFERENCIAL TEÓRICO}

Nessa parte será feita uma revisão da literatura utilizada até aqui para pesquisa a cerca do tema em questão. Partindo de um relato histórico das reformas da administração pública brasileira na visão de Costa (2008); seguida de uma discussão sobre algumas dessas reformas, por Bresser Pereira (1996); e uma análise dos motivos porque as reformas fracassam, (Rezende, 2004).

\subsection{Relato Histórico das Reformas Administrativas Brasileiras.}

Para Costa (2008), a organização do estado brasileiro começa a partir da chegada da Família Real Portuguesa ao Brasil em 1808; o que ele considera uma primeira reforma da administração pública brasileira.

A formação do governo português em terras brasileiras foi concebida nos moldes da organização administrativa em funcionamento em Lisboa até momentos antes da partida da corte para a colônia; ou seja, extremamente patrimonialista com criação de diversos órgãos sem utilidade, com intuito exclusivo de acomodar os chamados "amigos do rei". Mas não podemos ficar presos apenas aos pontos negativos dessa mudança de sede da Coroa Portuguesa, também encontraremos nela, eventos benéficos para a futura organização do estado brasileiro, tais como; a criação da Biblioteca Nacional, do Arquivo Militar, da Academia de Belas Artes e do Banco do Brasil, dentre outros; organismos que contribuíram muito para a consolidação do estado nacional brasileiro, como cita Costa (2008).

\footnotetext{
O fato é que a transferência da corte e mais tarde a elevação do Brasil a parte integrante do Reino Unido de Portugal constituiu as bases do Estado nacional, com todo o aparato necessário à afirmação da soberania e ao funcionamento do autogoverno. A elevação à condição de corte de um império transcontinental fez da nova administração brasileira, agora devidamente aparelhada, a expressão do poder de um Estado nacional que jamais poderia voltar a constituir-se em mera subsidiária de uma metrópole de além-mar. (COSTA, 2008, p.836)
}

Após o retorno da família real portuguesa a Lisboa e posteriormente a proclamação da independência do Brasil de Portugal, feita por Pedro I, então 
príncipe regente do Brasil, o Estado se organizou na forma de um Império que teve como apogeu da administração pública o período de Pedro II.

Com a chegada da República, mudanças na organização administrativa foram implementadas com o intuito maior de adequar a burocracia estatal à nova forma de governo do que melhorar a administração; não podemos considerar, ainda, essas mudanças como uma reforma administrativa, uma vez que o atendimento ao cidadão, por parte do Estado, continuava precário. Nem mesmo na economia tivemos mudanças bruscas com a chegada da República; a elite econômica influente saiu do círculo dos senhores de engenho de açúcar cariocas e nordestinos e passou às mãos dos cafeicultores paulistas, mas permanecemos com uma economia agrária e um estado fortemente centrado em práticas de clientelismo.

A fase conhecida como "República Velha" durou cerca de 40 anos e começou a perder espaço justamente quando teve início o primeiro surto de industrialização do país, essa diversificação da economia nacional foi, aos poucos, enfraquecendo a influência política da economia agrária. A insatisfação com a forma de administrar o estado e conduzir a política, adotada pela República Velha culminou com a Revolução de 1930, que levou ao poder o gaúcho Getulio Vargas.

Durante o governo Vargas, sobretudo a partir do golpe de estado de 1937, entrou em marcha um movimento em direção à burocratização do Estado brasileiro. Foram criados diversos órgãos com a finalidade de profissionalizar a administração pública e dotar o país de práticas administrativas mais modernas, com a finalidade de reduzir o patrimonialismo enraizado no Estado brasileiro. Dentre os esforços do governo Vargas nesse sentido, podemos destacar a criação de diversos organismos de gestão do Estado, com destaque para o Departamento de Administração do Serviço Público (DASP); cuja finalidade era elaborar orçamentos, recrutar e treinar servidores, racionalizar e normatizar as aquisições e contratos e gerir o estoque de material; podemos considerar esse período, e suas mudanças, como a primeira Reforma Administrativa brasileira, com viés inteiramente burocrático e inspiração Weberiana. Costa (2008) definiu assim, esse período:

A reforma administrativa do Estado Novo foi, portanto, o primeiro esforço sistemático de superação do patrimonialismo. Foi uma ação deliberada e ambiciosa no sentido da burocratização do Estado brasileiro, que buscava introduzir no aparelho administrativo do país a centralização, a impessoalidade, a hierarquia, o sistema de mérito, a separação entre o público e o privado. (COSTA, 2008, p. 846) 
Entre 1945 e 1967, ano da edição do Decreto-lei 200, a modernização da administração pública ficou praticamente parada. Esse decreto trazia a mais ampla reforma administrativa do país, muitas das boas práticas administrativas atuais estavam naquele decreto, tais como: as bases do controle interno e externo da administração, distinção entre administração pública direta e indireta e normas para aquisição e contratação de bens e serviços; mas como os objetivos desse decreto eram muito amplos e o governo não conseguiu executá-los na totalidade, a reforma fracassou.

Depois da reforma de 1967 e até meados da década de 1990, tivemos tímidas tentativas de modernização da administração pública nacional; por exemplo, o projeto de desburocratização dos serviços públicos em 1979; algumas tentativas já no governo Sarney, no período imediatamente pós-ditadura militar e as ações do governo Collor que acabaram por desmantelar a máquina administrativa pública brasileira.

Já no Governo Fernando Henrique Cardoso foi implementada uma nova reforma administrativa, capitaneada pelo professor Luis Carlos Bresser Pereira; cujo objetivo principal era mudar o modelo de administração pública brasileira de Burocrática para Gerencial. Conforme cita Costa (2008).

O Plano Diretor da Reforma do Aparelho de Estado tinha como proposta explícita inaugurar a chamada "administração gerencial", o que parece designar, como veremos, o fim da história da administração pública, espécie de panacéia redentora do estatismo patrimonialista e do ogro burocrático. (COSTA 2008, p. 863)

\subsection{Análises Comparativas das Reformas Administrativas Brasileiras.}

No entendimento de Bresser Pereira (1996), o que aconteceu na administração pública brasileira na década de 1930, foi a continuação de um movimento em direção à burocracia clássica que começou na Europa no final do século XIX, estendeu-se para os Estados Unidos da América no princípio do século XX, chegando até o Brasil em 1936. 
Não era condizente o modelo econômico capitalista e as democracias parlamentares que começam a surgir no século XIX com o modelo de administração patrimonialista, marca do estado absolutista, era necessária uma separação entre o público e o privado para que se garantisse 0 ambiente propício para 0 desenvolvimento do capitalismo industrial; Essa é a visão de Bresser Pereira (1996) sobre esse período.

\begin{abstract}
A administração pública burocrática foi adotada para substituir a administração patrimonialista, que definiu as monarquias absolutas, na qual o patrimônio público e o privado eram confundidos. Nesse tipo de administração o Estado era entendido como propriedade do rei. O nepotismo e o empreguismo, senão a corrupção, eram a norma. Esse tipo de administração revelar-se-á incompatível com o capitalismo industrial e as democracias parlamentares, que surgem no século XIX. É essencial para o capitalismo a clara separação entre o Estado e o mercado; a democracia só pode existir quando a sociedade civil, formada por cidadãos, distingue-se do Estado ao mesmo tempo em que o controla. (BRESSER PEREIRA, 1996, p. 4)
\end{abstract}

Para Bresser Pereira (1996), o modelo burocrático clássico, que é superior a administração patrimonialista, funcionou bem e atendeu aos seus objetivos enquanto os Estados eram pequenos, como os Estados liberais do século XIX, cujas funções basicamente se resumiam a garantir a propriedade e os contratos. Mas, no século $\mathrm{XX}$, quando o Estado se tornou grande, econômico e socialmente, quando as demandas dos administrados cresceram e se tornaram complexas, o modelo burocrático clássico se tornou ineficiente. Porque além de caro e lento não estava focado no atendimento ao usuário, mas nos controles.

A partir do início da segunda metade do século $X X$, com as grandes funções atribuídas aos Estados, tais como, prover educação, saúde, cultura, administrar previdência e outras, começam a surgir as críticas à lentidão da administração burocrática em relação ao atendimento de tantas demandas. Todo esse contexto aliado às comparações aos novos modelos de administração que começam a ser implantados nas empresas privadas, que se mostram mais flexíveis e eficientes, acaba por desencadear, já na década de 1970, uma crise no Estado que acabará por levar a uma crise do seu modelo de gestão.

A partir da década de 1980, inicia-se, sobretudo nos países mais desenvolvidos, um movimento em direção ao modelo de administração pública gerencial. Com novos paradigmas, por exemplo, descentralização administrativa, 
maior autonomia gerencial dos administradores públicos, foco no atendimento ao cidadão e etc. Conforme cita Bresser Pereira (1996).

\begin{abstract}
Após a II Guerra Mundial há uma reafirmação dos valores burocráticos, mas, ao mesmo tempo, a influência da administração de empresas começa a se fazer sentir na administração pública. As idéias de descentralização e de flexibilização administrativa ganham espaço em todos os governos. Entretanto a reforma da administração pública só ganhará força a partir dos anos 70 , quando tem início a crise do Estado, que levará à crise também a sua burocracia. Em conseqüência, nos anos de 1980 inicia-se uma grande revolução na administração pública dos países centrais em direção a uma administração pública gerencial. (BRESSER PEREIRA, 1996, p. 5)
\end{abstract}

Na visão de Bresser Pereira (1996), a percepção, no Brasil, de que o modelo burocrático tradicional já não atendia às necessidades gerenciais do estado começaram a ser observados já na década de 1960, durante a ditadura militar que governava o país.

Em 1967 foi editado o Decreto-lei 200, que introduzia na administração pública brasileira, modernas ferramentas de gestão, por exemplo: planejamento, orçamento, descentralização administrativa e controle focado nos resultados, dentre outras. Mesmo assim essa proposta de reforma não conseguiu atingir seus objetivos por alguns erros cometidos na execução, que acabaram por enfraquecer a administração pública central e não criar mecanismos de formação de profissionais de alto escalão da administração, conforme relata Bresser Pereira (1996).

O Decreto-Lei 200 teve, entretanto, duas conseqüências inesperadas e indesejáveis. De um lado, ao permitir a contratação de empregados sem concurso público, facilitou a sobrevivência de práticas patrimonialistas e fisiológicas. De outro lado, ao não se preocupar com mudanças no âmbito da administração direta ou central, que foi vista pejorativamente como "burocrática" ou rígida, deixou de realizar concursos e de desenvolver carreiras de altos administradores. (BRESSER PEREIRA, 1996, p.7)

Após o Decreto-lei 200 de 1967, teve ainda o programa de desburocratização do Estado, implantado entre 1979 e 1983 pelo então ministro de estado da desburocratização Hélio Beltrão, que foi também um dos idealizadores do Decreto-lei 200.

Com a chegada da Nova República e a Constituição de 1988, segundo Bresser Pereira (1996), houve um retrocesso em termos de administração pública. A nova Carta Magna promoveu um retrocesso, falando em termos de administração 
gerencial, na verdade uma volta à administração burocrática clássica, que foi implantada na década de 1930.

Essa volta à burocracia clássica é atribuída por Bresser Pereira (1996) ao ceticismo com que as forças democráticas, que atuaram na queda da ditadura, tinham em relação às práticas clientelistas adotadas no período militar para contratação de pessoal na administração indireta; juntamente com a alta burocracia da administração direta que havia sido desprezada e desvalorizada pela prática do regime militar de contratar pessoal com alta qualificação para administração pública através das empresas estatais, em detrimento da Administração Direta.

A consolidação de privilégios e enrijecimento da máquina pública implantada pela Constituição de 1988, aliada com a edição da Lei 8112/90 (estatuto dos servidores públicos civis da União), que colocou 400 mil servidores de autarquias e fundações públicas na condição de servidor estatutário, com direito a aposentadoria integral e outros benefícios; foi um dos responsáveis pelo aumento do gasto público e desequilíbrio das contas públicas que ocorreram nos anos finais da década de 1980 e início da década de 1990, na visão de Bresser Pereira (1996).

\footnotetext{
Em síntese, o retrocesso burocrático da Constituição de 1988 foi uma reação ao clientelismo que dominou o país naqueles anos, mas também foi uma afirmação de privilégios corporativistas e patrimonialistas incompatíveis com o ethos burocrático. Foi, além disso, uma conseqüência de uma atitude defensiva da alta burocracia, que, sentindo se acuada, injustamente acusada, defendeu-se de forma irracional. (BRESSER PEREIRA, 1996, p. 10)
}

A última reforma administrativa abordada por Bresser Pereira (1996) é a Reforma ocorrida a partir de 1995, idealizada por ele mesmo, durante o governo Fernando Henrique Cardoso, do qual Bresser Pereira fazia parte na condição de titular da pasta do Ministério da Administração e Reforma do Estado.

Essa Reforma foi muito ampla e teve um caráter de mudança de paradigma, porque seu intuito era modificar o modelo de administração do Estado definitivamente, do burocrático clássico para a administração gerencial.

Nessa Reforma, de acordo com Bresser Pereira (1996) o Estado é dividido em quatro setores: núcleo estratégico do Estado, atividades exclusivas do Estado, serviços não exclusivos ou competitivos, produção de bens e serviços para o mercado. 
O núcleo estratégico do Estado, que é composto basicamente pela cúpula dos três poderes mais o Ministério Público deveria ser exercido pelo Estado, através de ferramentas de administração, como os contratos de gestão, que seriam negociados com os órgãos executores; no segundo grupo, as atividades exclusivas do Estado, que corresponde às áreas de regulação, fiscalização e polícia, deveriam ser exercidas por agências com dirigente nomeado pelo Ministro a que estivesse ligada e com grande autonomia; no setor dos serviços não exclusivos ou competitivos, seriam colocadas as universidades, museus, escolas técnicas, hospitais e outras; essas instituições seriam transformadas em organizações sociais que receberiam subsídios do Estado para prestar esses serviços, mas não seriam executados por servidores públicos. Por último teríamos o setor de produção de bens e serviços para o mercado, que engloba as empresas estatais e que seriam privatizadas. Conforme cita Bresser Pereira (1996)

\begin{abstract}
A modernização ou o aumento da eficiência da administração pública será o resultado a médio prazo de um complexo projeto de reforma, através do qual se buscará a um só tempo fortalecer a administração pública direta ou o "núcleo estratégico do Estado", e descentralizar a administração pública através da implantação de "agências autônomas" e de "organizações sociais" controladas por contratos de gestão. (BRESSER PEREIRA, 1996, p. 18)
\end{abstract}

\title{
2.3 Os Motivos do Fracasso das Reformas Administrativas.
}

Rezende (2004) faz um estudo sobre as causas do fracasso das diversas reformas administrativas ocorridas em vários países do mundo. Nesse trabalho o autor dispensa atenção especial a onda de reformas implementadas mundo afora na década de 1990; não que esqueça outras reformas em outras épocas, mas a atenção especial é para esse período.

Com relação ao Brasil ele aborda mais especificamente a Reforma Administrativa implantada durante o governo Fernando Henrique Cardoso, mais precisamente a partir de 1995, sob responsabilidade do Ministério da Administração e Reforma do Estado, capitaneada pelo ministro à época, Luiz Carlos Bresser Pereira.

Rezende (2004) aponta como motivo principal para essa onda de reformas, tanto nos Estados desenvolvidos quanto nos Estados em desenvolvimento, a 
incapacidade desses Estados de atender às crescentes demandas dos seus administrados e à necessidade de reduzir seus custos para conseguir fazer frente a essas demandas.

A incapacidade de atendimento da demanda, segundo Rezende (2004), está diretamente ligada à ineficiência da máquina do Estado que se tornara obsoleta, devido ao modelo de administração burocrática clássica que era empregado na maioria desses Estados; aliada a diversificação das demandas sociais que os Estados foram acumulando ao longo de suas trajetórias. Já a necessidade de reduzir os custos desses Estados, fazia-se necessária porque eles além de assistirem, nas últimas décadas, a um aumento das despesas com o atendimento das demandas dos administrados, também testemunharam um crescimento da sua administração levando a um aumento brutal das suas despesas com o aparato administrativo. Para o autor, esse quadro eleva o clamor dentro e fora do governo pelas reformas, que começam nos países desenvolvidos e em seguida chegam aos países em desenvolvimento. Elas têm algo em comum nos dois grupos de países, o aumento do desempenho da administração pública, através da perseguição de dois objetivos: o ajuste fiscal e a mudança institucional.

Mas é justamente na conjugação desses dois objetivos que Rezende (2004) detecta a causa da falha das reformas, porque no bojo das reformas eles são antagônicos. Enquanto no objetivo mudança institucional as reformas tendem a flexibilizar procedimentos e descentralizar serviços para ganhar eficiência; no ajuste fiscal a tendência é aumentar os controles e centralizar as decisões para melhorar a qualidade dos gastos. Diante desse quadro os atores envolvidos, sobretudo os ligados às áreas de controle, inclinam-se a não cooperar com as ações de mudança institucional, porque entendem que com a redução de órgãos e descentralização o controle será mais difícil.

Nos países em desenvolvimento esse antagonismo dos objetivos acabou por se agravar, porque além das resistências naturais citadas no parágrafo anterior, tinha-se ainda o problema do descontrole das contas públicas; para fazer frente a esse problema, dentro do próprio governo, o ajuste fiscal ganhou prioridade em detrimento da mudança institucional. Conforme cita Rezende (2004). 
Estado. A Câmara da Reforma, que seria coordenada pelo Chefe da Casa Civil da Presidência da República, foi concebida para envolver os ministérios na tarefa de redução do grau de conflito nas principais decisões relativas à formulação e implementação da política da reforma. Por sua vez, o Conselho da Reforma - criado pelo Decreto-lei no 1738 de 1995 - desempenharia um papel consultivo, tendo por objetivo primeiro ser o espaço coletivo para o debate e produção de propostas políticas a serem levadas à Câmara da Reforma do Estado. O Conselho da Reforma deveria ser composto de doze membros indicados pelo presidente, por um mandato de três anos, envolvendo representantes da sociedade civil, do setor privado, das universidades e ex-funcionários públicos federais.Com a criação e o funcionamento dessas duas instituições, a reforma pretendia aumentar a participação social sobre a formulação e implementação, bem como reduzir os conflitos e os problemas de ação coletiva no processo de encaminhamento da reforma no plano operacional e decisório. Todavia, tais instituições não foram fortalecidas durante a reforma, evidenciando um problema coletivo de cooperação dos principais atores no governo com as propostas de transformação das estruturas de controle no interior da burocracia brasileira. Sem a cooperação coletiva dos demais atores com poder decisório no governo, o Mare ficou isolado para lidar com a cooperação dos diversos ministérios, sobretudo para implementar as propostas de mudança institucional, o que dificultou sobremaneira a implementação da reforma (REZENDE,2004, p. 32). 


\section{MÉTODOS E TÉCNICAS DE PESQUISA}

"Pesquisa é um procedimento formal, com método de pensamento reflexivo, que requer um tratamento científico e se constitui no caminho para conhecer a realidade ou para descobrir verdades parciais" (LAKATOS e MARCONI, 2010, p.139).

\subsection{Tipo e descrição geral da pesquisa (técnicas de pesquisa ou estratégias escolhidas para coletar os dados)}

A presente pesquisa utilizou o método qualitativo, de acordo com Zanella (2006), esse método preocupa-se em conhecer a realidade segundo a perspectiva dos sujeitos participantes da pesquisa, sem medir ou utilizar elementos estatísticos para análise dos dados.

Levando em conta o tema apresentado e os objetivos que se desejou atingir com este trabalho, a presente pesquisa pode ser classificada como exploratória. Uma vez que o trabalho se propõe a analisar um tema que é objeto de discussão desde a segunda metade da década de 1990, sobre o qual já existe uma literatura especializada bastante ampla, bem como as conseqüências desse fato em nossa sociedade. As técnicas de pesquisa utilizadas foram: a pesquisa bibliográfica e entrevistas estruturadas com integrantes da carreira de Especialista em Políticas Públicas e Gestão Governamental e servidores integrantes de outras carreiras, mas que no momento estão em cargos de confiança relacionados à carreira, com a finalidade de enriquecer o trabalho.

A pesquisa bibliográfica, ou de fontes secundárias, abrangia toda a bibliografia já tornada pública em relação ao tema de estudo, desde as publicações avulsas, boletins, jornais, revistas, livros, pesquisas, monografias, teses, material cartográfico etc., até meios de comunicação oral: rádio, gravações em fita magnética e audiovisuais: filmes e televisão. Sua finalidade foi colocar o pesquisador em contato direto com tudo o que foi escrito, dito ou filmado sobre assunto em tela, inclusive conferências seguidas de debates que tenham sido transcritos por alguma forma, quer publicadas, quer gravadas. (LAKATOS e MARCONI, 2010, p.166). 


\subsection{Caracterização da organização, setor ou área.}

A coleta de dados que subsidiaram a presente pesquisa foi feita junto ao Ministério do Planejamento Orçamento e Gestão, que é o órgão do Governo Federal responsável pela carreira de Especialista em Políticas Públicas e Gestão Governamental.

\subsection{População e amostra}

A utilização da técnica de entrevista nesse trabalho teve o intuito de enriquecer a qualidade do trabalho. Foram realizadas três entrevistas com integrantes da carreira de Especialistas em Políticas Públicas e Gestão Governamental e gestores da carreira junto ao Ministério do Planejamento Orçamento e Gestão:

1) Maria da Penha Barbosa da Cruz - Coordenadora-Geral da Gestão da Carreira de Especialista em Políticas Pública e Gestão Governamental da Secretaria de Gestão do Ministério do Planejamento Orçamento e Gestão.

2) Sandro Eli Malcher de Alencar - Coordenador da Coordenação-Geral da Secretaria de Gestão do Ministério do Planejamento Orçamento e Gestão.

3) Ciro Campos Christo Fernandes - Diretor de Articulação e Inovação Institucional da Secretaria de Gestão do Ministério do Planejamento Orçamento e Gestão.

A divulgação dos nomes, cargos e instituições dos entrevistados, bem como o conteúdo de suas entrevistas foi autorizado por meio de TERMO DE CONSENTIMENTO LIVRE E ESCLARECIDO (apêndice B), assinado por todos.

Os entrevistados foram escolhidos dentre integrantes da Carreira de EPPGG ou gestores dessa, com notório conhecimento sobre o assunto, experiência em funções ligadas à gestão da carreira e conhecimento da história do desenvolvimento da carreira dentro da administração pública. Garantindo credibilidade às suas opiniões e preferência pela divulgação das suas identidades. 


\subsection{Instrumentos de pesquisa}

Foi usado como instrumento de pesquisa a pesquisa bibliográfica e a entrevista estruturada. O primeiro com a finalidade de realizar um relato histórico do objeto de pesquisa e dar suporte teórico às questões levantadas na introdução; o segundo instrumento, composto por três perguntas, tem a finalidade de conhecer a percepção dos integrantes da carreira de Especialista em Políticas Públicas e Gestão Governamental e os gestores dessa carreira acerca do objeto de pesquisa.

A primeira pergunta deu ao entrevistado a oportunidade de formular uma resposta mais genérica e atendeu ao objetivo geral desse trabalho.

A segunda pergunta, que foi subdividida em 2 e 2.1, foi mais focada, com a finalidade de conhecer a percepção que o entrevistado tem das conseqüências do objeto de estudo no fortalecimento do Núcleo Estratégico do Estado, um dos objetivos da Reforma Administrativa de 1995.

A terceira pergunta exigiu dos entrevistados uma reflexão a respeito da eficácia das medidas governamentais, relativas à reestruturação da carreira de EPPGG, implementadas para atender o pretendido na Reforma Administrativa de 1995 em relação ao fortalecimento do Núcleo Estratégico do Estado ou, se for o caso, o que poderia ter sido acrescentado para o sucesso das ações.

As entrevistas foram realizadas nos dias 18 e 19 de outubro de 2010 e tiveram duração média de 15 minutos, tendo seu conteúdo registrado por aparelho gravador para que o entrevistador possa concentrar a sua atenção nas respostas dos entrevistados. Os resultados das entrevistas, após transcrição sem comprometimento do conteúdo, estão disponíveis nos apêndices $\mathrm{C}$ a $\mathrm{E}$. 


\section{RESULTADOS DA DISCUSSÃO}

\subsection{A carreira de EPPGG antes da Reforma Administrativa de 1995.}

A carreira de Especialista em Políticas Públicas e Gestão Governamental (EPPGG) começou a ser pensada em 1982, quando o Embaixador Sérgio Paulo Rouanet, a pedido do Departamento de Administração do Serviço Público (DASP), realizou um estudo para analisar a viabilidade de se implementar no Brasil uma escola de governo nos moldes da ENA francesa. O Embaixador Rouanet constatou que era necessário não apenas a criação de uma escola para formar a elite do serviço público, mas também que fosse garantido aos egressos dessa escola o acesso aos cargos de alto escalão da burocracia brasileira. Caso contrário não faria sentido nem para alunos, nem para escola a sua existência. Conforme cita Rouanet (2005).

Assim, o Relatório intitulado Criação no Brasil de uma Escola Superior de Administração Pública (1982), recomendou a criação de carreira ou cargos de natureza especial para o exercício de atividades de direção, supervisão e assessoramento nos escalões superiores da burocracia, como solução para a alocação dos egressos da futura Escola. (ROUANET, 2005, pág.81)

A partir de 1985 inicia-se o governo de José Sarney, primeiro presidente civil desde março de 1964, quando foi instalada a ditadura militar no país. Nesse contexto de redemocratização do país o governo tenta implementar uma reforma administrativa que teria como objetivos principais reduzir os gastos públicos e dotar a administração pública de um corpo funcional mais adequado aos novos tempos de democracia.

Dentro dessa perspectiva a comissão encarregada da reforma concluiu que era necessária a criação de uma escola de governo. Essa escola seria responsável pela formação do pessoal de nível superior da administração, que modernizaria e tornaria mais eficiente o serviço público.

O relatório feito pelo Embaixador Sérgio Rouanet, em 1982, influenciou diretamente a criação da escola de governo prevista na reforma do governo Sarney, bem como a carreira de EPPGG; porém os dois projetos não foram implementados 
juntos, como previa o relatório de Rouanet. A Escola Nacional de Administração Pública (ENAP) foi criada em 1986, mas a carreira de EPPGG apenas em 1989.

Com essas duas iniciativas o governo começava a colocar em prática 0 processo de formação de uma burocracia especializada e capaz de suprir a Administração Direta de quadros qualificados para assumir postos nos escalões superiores do governo. A formação desse corpo funcional garantia ao Estado continuidade na administração, uma vez que esses profissionais não deixariam a administração direta cada vez que houvesse uma mudança de governo, prática comum aos dirigentes vindos de fora da administração pública ou da administração indireta.

Mas o caminho para consolidação da carreira de EPPGG não foi fácil, o seu projeto de criação foi enviado ao Congresso Nacional em 1987, mas só foi aprovado em 1989, quando já havia sido realizado o primeiro concurso e o curso de formação já estava bem avançado, como cita Aldino Graef, Ciro Campos e Luiz Alberto Santos em artigo publicado na Revista do Serviço Público em 1994.

A efetiva instituição da carreira só veio ocorrer depois de realizado o primeiro concurso e com o curso de formação bastante avançado. Após dois anos de tramitação no Congresso Nacional, onde a proposta foi aprovada em 4 turnos de discussão e votação, foi constituída pela Lei 7384 de 06 de outubros de 1989, a carreira de Especialista em Políticas Públicas e Gestão Governamental. Nesta lei, optou-se pela organização dos Gestores enquanto carreira, tendo como requisitos de ingresso a realização de concursos público de provas e títulos e a conclusão, com aproveitamento, de curso de formação ministrado pela ENAP. (ALDINO, FERNANDES, SANTOS, 1994, p. 92)

Foram inúmeras as dificuldades que rondaram a criação desta carreira, além do país estar às voltas com a transição de um regime ditatorial para uma democracia, outros problemas também afligiam o governo, tais como, descontrole inflacionário e situação econômica complicada, dentre outros. Fatores que fizeram com que a reforma administrativa perdesse força dentro do governo, por conseqüência o projeto de implementação da carreira de EPPGG. Não bastasse tudo isso, o perfil generalista e a ampla mobilidade dos gestores, que eram as bases do projeto, despertaram a atenção de grupos políticos e outras carreiras estruturadas há mais tempo, que eram contrárias a criação da carreira de EPPGG, provavelmente temendo perder espaço e poder na administração pública; esses grupos passaram a trabalhar contra a criação da carreira. 
Mesmo com todas essas dificuldades, a Secretaria de Administração Pública (SEDAP), que no governo Sarney substituiu o DASP, e era a responsável pela Reforma Administrativa, realizou o primeiro concurso para o cargo de EPPGG, mesmo antes da regulamentação da carreira, como já foi mencionado. Esse concurso foi realizado em 1989 e foi um dos mais concorridos do país na época; os aprovados tinham uma formação diversa (engenheiros, economistas, bacharéis em direito, administradores, historiadores, arquitetos e outros) atendendo ao perfil que foi traçado para o cargo.

Quadro demonstrativo dos aprovados no $1^{\circ}$ concurso para EPPGG

\begin{tabular}{|l|c|c|c|}
\hline $\begin{array}{l}\text { Formação } \\
\text { profissional } \\
\text { dos egressos } \\
\text { da ENAP }\end{array}$ & $\mathbf{1}^{\text {a } \text { formação }}$ & 2a formação & Total \\
\hline Engenharia & 31 & 4 & 35 \\
\hline Economia & 24 & 3 & 27 \\
\hline Direito & 15 & 2 & 17 \\
\hline Administração & 10 & 3 & 13 \\
\hline História & 5 & 1 & 6 \\
\hline Arquitetura & 4 & - & 19 \\
\hline Outros* & - & - & 4 \\
\hline
\end{tabular}

* CONTABILIDADE (2), FILOSOFIA (2), FÍSICA (2), INFORMÁTICA (2), MEDICINA (2), RELAÇÕES INTERNACIONAIS (2), CIÊNCIA POLÍTICA (1), ESTATíSTICA (1), LETRAS (1), MATEMÁTICA (1), PEDAGOGIA (1), PUBLICIDADE E PROPAGANDA (1), TEOLOGIA (1). FONTE: Artigo publicado na Revista do Serviço Público em 1994, por Aldino Graef, Ciro Campos e Luiz Alberto Santos. Pag. 93.

A primeira turma de EPPGGs tomou posse em fevereiro de 1990, após a superação de várias dificuldades e obstáculos à criação dessa carreira; enfim estava empossada a primeira turma composta por 93 gestores. Porém, as dificuldades da carreira não haviam sido superadas, pelo contrário, estavam apenas começando. A posse dessa primeira turma se deu num contexto político totalmente adverso; iniciava-se o governo do presidente Fernando Collor de Melo, que ficou marcado, na administração pública, por um grande desmantelamento da máquina pública federal, com extinções e fusões de vários órgãos, demissões e colocação em disponibilidade de milhares de servidores, enxugamento da máquina pública, arrocho salarial e 
enfraquecimento da burocracia estatal. Diante disso, foi apresentado para aquele Governo um projeto, que fora gestado no Governo anterior, através do qual se criava uma carreira composta de 960 cargos a serem preenchidos em sucessivos concursos; com alto salário e espaço para ocupar postos chaves nos escalões superiores da Administração Federal. O Governo Collor nomeou apenas os que haviam sido aprovados no concurso realizado em 1988, os distribuiu por vários ministérios e não deu continuidade ao processo de formação e admissão dos gestores, como era previsto no projeto inicial. A esse respeito Santos e Cardoso escreveram em 2005.

\begin{abstract}
A descontinuidade do projeto, agravada pela posse de Fernando Collor de Mello na Presidência da República em março de 1990 e a implantação de uma política deliberada de desmonte do aparelho estatal na Administração Federal, fez com que o cronograma de provimento fosse abandonado. Não houve novos concursos até 1995, quando, dos 93 Gestores Governamentais, somente cerca de 60 ainda permaneciam na Carreira, em sua quase totalidade detentores de cargos de direção e assessoramento em diversos ministérios, autarquias, na Presidência da República e em assessorias do próprio Congresso Nacional (SANTOS e CARDOSO, CLAD, 2000, p. 8).
\end{abstract}

A despeito das dificuldades e percalços pelos os quais passaram a criação da carreira e a nomeação dos primeiros gestores, eles foram para suas unidades de lotação, começaram a trabalhar e colocar em prática todo o conhecimento que possuíam em prol do desenvolvimento de vários projetos em diversas áreas. Em pouco tempo a atuação dos gestores se tornou um caso de sucesso. Eles participaram de inúmeros projetos importantes do Governo Federal no período de 1990 a 1993, por exemplo: Elaboração do Projeto de Lei Orgânica para a Administração Pública Federal (1989 e 1990); Implantação do Conselho Deliberativo do Fundo de Amparo ao Trabalhador (1990) e Implementação do Programa Federal de Desregulamentação (1990 a 1993). Outro dado que demonstra o sucesso dos profissionais dessa carreira dentro da Administração Pública é a quantidade deles em cargos de confiança. Em apenas quatro anos de exercício sessenta e nove por cento dos profissionais dessa carreira encontravam-se em cargos de confiança. Com destaque para um Secretário Executivo e um Secretário Geral de Ministério.

Apesar do brilhante desempenho desses profissionais dentro da Administração Pública a sua carreira continuava desvalorizada. Causando 
desmotivação aos seus profissionais e evasão de seu contingente. Em 1994 apenas um concurso havia sido realizado e dos 93 gestores empossados em 1990 apenas 62 permaneciam na carreira. Paralelamente os que permaneciam na carreira assistiam a uma brutal perda de valor de seus salários, quando comparados a outras carreiras de mesmo nível dentro da Administração Pública Federal, por exemplo: em 1989, quando foi realizado o primeiro concurso, a remuneração inicial de um Gestor era algo em torno de 1.500 dólares americanos, enquanto a de um Auditor Fiscal do Tesouro Nacional era pouco mais de 2.000 dólares. Já em 1993 o Gestor recebia pouco mais de 500 dólares, enquanto o Auditor recebia cerca de 3.000 dólares.

\subsection{A eficácia da reestruturação da carreira de EPPGG para o fortalecimento do Núcleo Estratégico do Estado.}

Em 1994, durante a campanha eleitoral para a Presidência da República os dois principais candidatos, Fernando Henrique Cardoso e Luis Inácio da Silva, reconheceram em seus programas de governo a necessidade de recuperar a capacidade de gestão da Administração Direta Federal. Bem como a importância de recrutar quadros dirigentes para essa administração formados pela Escola Nacional de Administração Pública.

Com a posse no cargo de Presidente da República de Fernando Henrique Cardoso em 1995, candidato vitorioso no pleito do ano anterior, foi colocada em andamento uma ambiciosa reforma administrativa. Dirigida pelo professor Luiz Carlos Bresser Pereira, que acabara de assumir o recém criado Ministério da Administração e Reforma do Estado (MARE).

A Reforma previa uma descentralização dos serviços do estado, através da criação de agências autônomas para execução das atividades exclusivas; as atividades não exclusivas ou competitivas seriam prestadas por organizações sociais através de subsídios do governo. Como disse Fernandes (2010) em sua entrevista para esse trabalho, (Apêndice E): "Paradoxalmente, para descentralizar a parte operacional do Estado, como previa a Reforma, era necessário fortalecer o Núcleo Estratégico do Estado." 
Ao chegar ao governo com a missão de formular essa grande Reforma Administrativa, Bresser Pereira tomou conhecimento da existência da carreira de EPPGG e utilizou vários desses gestores na montagem da sua equipe, que seria responsável pelo trabalho de formulação da Reforma Administrativa.

A proximidade do trabalho com esses profissionais e o conhecimento da sua carreira e seu perfil de formação fez com que Bresser Pereira enxergasse nessa carreira uma importante ferramenta para o objetivo de fortalecer o Núcleo Estratégico do Estado, que estava previsto na proposta da Reforma Administrativa. A partir dessa interação Bresser Pereira encampou a tarefa de reestruturar a carreira de EPPGG, retomando a partir de 1995 o processo de concursos e formação dos Gestores.

$\mathrm{Na}$ política de fortalecer o Núcleo Estratégico do Estado foi implementado um processo de valorização das carreiras que compõem o chamado Ciclo de Gestão: Planejamento e Gestão, Finanças e Controle, Negócio Exterior, Planejamento e Pesquisa (IPEA) e Especialista em Políticas Públicas e Gestão Governamental. Sem dúvidas todas essas carreiras passaram a ser mais valorizadas a partir da Reforma Administrativa de 1995. Mas a carreira de EPPGG foi a mais beneficiada, porque saiu de uma situação de paralisia, com apenas um concurso realizado em 1989, quase sendo extinta nesse intervalo, para uma fase de revigoramento, com realização sistemática de concursos a partir de 1995 e melhoria de salários, como mencionou Maria da Penha (2010) em sua entrevista para esse trabalho, (Apêndice $\mathrm{C}$ ): "A construção e valorização de uma carreira com as características idêntica as dos EPPGG só entraram de vez na agenda política do governo a partir da Reforma de 1995."

A partir da Reforma de 1995, os integrantes da carreira de EPPGG passaram a ser demandados por diversos órgãos da Administração Direta, uma vez que, pelo seu perfil de formação, eram os profissionais mais sintonizados com as propostas da Reforma Administrativa de 1995.

Os Gestores foram alocados nos diversos ministérios e em muitos deles ocupando funções de alta relevância dentro da Administração Pública; passaram a trabalhar junto aos especialistas de diversas carreiras na formulação de políticas públicas, fazendo a ligação entre a cúpula dos órgãos em que trabalhavam e as instâncias executoras das políticas públicas traçadas. Outra marca dessa reestruturação da carreira foi a volta da mobilidade dos gestores, passando por 
vários órgãos e Ihes propiciando um conhecimento global da Administração Pública, fortalecendo o perfil generalista que está embutido na sua formação. A esse respeito Maria da Penha (2010) afirmou em sua entrevista.

O perfil generalista do gestor e sua visão global da Administração eram complementares ao conhecimento específico dos especialistas integrantes de outras carreiras, enriquecendo a formulação das políticas públicas (CRUZ, 2010, Apêndice C).

A criação da Carreira de EPPGG, desde quando começou a ser pensada em 1982 pelo o Embaixador Rouanet, tinha como objetivo dotar a Administração Direta Federal de um quadro de servidores estáveis, de nível superior, bem qualificado e preparado para trabalhar na formulação das políticas públicas do país. Essa fórmula garantiria continuidade às ações do estado, independente das mudanças de governo.

Para atender ao objetivo de fortalecer o Núcleo Estratégico do Estado, previsto na Reforma de 1995, o governo adotou a política de valorizar as carreiras do Ciclo de Gestão, melhorando seus salários, qualificando mais seus integrantes e estabelecendo cronograma de concursos para garantir a reposição de seus quadros. Porém, a carreira de EPPGG estava completamente desestruturada, com um quadro que não chegava a dez por cento do efetivo previsto na Lei que a criou.

Não era objetivo da Reforma criar uma carreira específica para atuar na gestão do Estado e implementar dentro da máquina pública a referida Reforma. Mas o governo, mais especificamente o ministro Bresser Pereira, enxergou nos EPPGGs o profissional com perfil ideal para fazer a comunicação entre as diretrizes da cúpula do governo, as áreas técnicas e executivas da máquina pública e os anseios da sociedade, além de disseminar dentro da Administração a nova filosofia de gestão. Essa impressão que o Ministro Bresser Pereira teve dos EPPGGs, deve-se, principalmente, à formação dos integrantes da carreira e as características de mobilidade e transversalidade que foram estabelecidas no seu projeto de criação. Diante dessa realidade o governo percebeu que reestruturar essa carreira, aumentar o seu contingente e distribuí-los por toda a Administração Pública seria uma ferramenta muito importante para atingir o objetivo de fortalecer o Núcleo Estratégico do Estado. 
Depois de resolvido que reestruturar a carreira de EPPGG seria muito bom para o desenvolvimento da Reforma Administrativa, o segundo passo do governo nessa direção foi suprir os cargos vagos na carreira e distribuí-los pelos diversos órgãos do Governo Federal. Pois esses profissionais fariam a ligação entre a parte política e administrativa dessa máquina, articulando a vontade política com a capacidade de gestão do governo, afinal essa é a essência da missão dessa carreira. Conforme consta no relatório da Secretaria de Gestão do Ministério do Planejamento Orçamento e Gestão (2009).

\subsection{PAPEL DOS EPPGGs}

EPPGG tem um papel governamental mais amplo e é um recurso corporativo responsável por:

\section{Formulação da Política Pública}

EPPGG facilita e apóia a formulação da política pública, garantindo que os grandes decisores recebam propostas políticas bem formuladas e, além disso, aconselha todos os setores do governo.

Implementação da Política Pública

EPPGG apóia os grandes decisores, garantindo que as políticas sejam implementadas eficientemente, e efetivamente, e que sejam cuidadosamente monitoradas e avaliadas.

\section{Eficiência governamental}

EPPGG desenvolve e implementa políticas e programas para aprimorar a organização e o funcionamento da máquina governamental nos níveis institucionais macro e individual. (SECRETARIA DE GESTÃO DO MPOG, 2009, P. 104)

Passados quinze anos do início da implementação da Reforma Administrativa, a carreira de EPPGG está sedimentada na Administração Pública Federal, seus profissionais bastante requisitado pelos diversos órgãos da Administração Pública e a capilaridade de lotação de seus integrantes atingiu patamares que nenhuma outra carreira do serviço público conseguiu. Os gestores estão presentes em praticamente quase todos os órgãos da Administração Direta Federal e algumas Administrações Estaduais, dos 960 cargos previstos na Lei que criou a carreira, 888 estão preenchidos.

Avaliar os resultados da reestruturação da carreira de EPPGG para o fortalecimento do Núcleo Estratégico do governo é algo muito difícil e subjetivo, como o é fazer essa avaliação com relação às outras carreiras do Ciclo de Gestão; porém, com um complicador a mais para analisar a carreira de EPPGG, o seu perfil generalista e a mobilidade dos seus integrantes, que torna a mensuração dos resultados ainda mais subjetivos. Mais alguns dados podem nos ajudar nessa 
avaliação, tais como o número de projetos estratégicos de governo dos quais seus integrantes participaram ao longo desses anos, a quantidade de cargos de confiança que seus integrantes ocupam e outros. Também serve como referência a opinião, positiva e unânime a esse respeito, dos especialistas que entrevistamos.

Fica difícil avaliar o impacto da reestruturação da carreira de EPPGG para o fortalecimento do Núcleo Estratégico do Estado, uma vez que é difícil mensurar um trabalho dessa natureza. Mas o fato de termos mais de sessenta por cento dos atuais 888 Gestores que integram a carreira em cargos de confiança no governo é uma prova da efetividade dessa carreira no fortalecimento do Núcleo Estratégico do Estado. Também entendo que embora tenha sido bem sucedida essa iniciativa do governo, ela não se deu de modo igual em todos os órgãos, em algumas áreas como Presidência da República e Ministério da Educação esse profissionais foram melhores aceitos e aproveitados. (CRUZ, 2010, Apêndice C).

Foi sim eficaz a reestruturação da carreira de EPPGG para o fortalecimento do Núcleo Estratégico do Estado, bem como o fortalecimento das demais carreiras do Ciclo de Gestão. Porém essa eficácia será maior quando o governo resolver o problema do descompasso entre as áreas de formulação e execução das políticas públicas. Uma vez que as áreas de formulação dessas políticas avançaram bastante a partir daquela Reforma, mas nas áreas de execução esse avanço foi muito pequeno. (ALENCAR, 2010, Apêndice D).

A reestruturação da carreira de EPPGG foi eficaz para o fortalecimento do Núcleo Estratégico do Estado, porém a reformulação das Secretarias e Ministérios, que estava prevista na Reforma, avançou muito pouco inibindo esse fortalecimento. O fortalecimento do Núcleo Estratégico não é algo acabado dentro da Administração Pública, é um processo a se completar. Portanto, a inserção dos Gestores na Administração Pública é também uma agenda atual, que deve continuar independente do governo que esteja dirigindo o país. $\mathrm{O}$ ingresso dos Gestores na Administração Pública foi como uma chuva num terreno que sofria de uma seca longa; onde caiu uma gota dessa água, alguma coisa germinou. (FERNANDES, 2010, Apêndice E).

\section{CONCLUSÃO E RECOMENDAÇÕES}

Esse trabalho teve como proposta fazer uma análise dos impactos da Reforma Administrativa de 1995 sobre o Núcleo Estratégico do Estado, à luz da reestruturação da Carreira de Especialista em Políticas Públicas e Gestão Governamental (EPPGG). Conforme visto, fortalecer esse Núcleo era um dos objetivos daquela Reforma e para tanto a estratégia era povoá-lo com servidores 
capacitados, sintonizados com as novas propostas de administrar o Estado e com visão holística da Administração Pública.

Melhorar a qualidade das práticas administrativas públicas no Brasil, bem como os processos de recrutamento e formação dos seus servidores, foi preocupação recorrente nas iniciativas das reformas administrativas brasileiras, desde a Reforma implantada por Getúlio Vargas na década de 1930. Procurou-se, já naquela época, modernizar as práticas gerenciais do Estado; melhorar a forma de recrutamento dos seus servidores, através da utilização dos concursos públicos como forma de acesso; descentralizar atividades, através da criação de empresas estatais; e, sobretudo, tentar eliminar as práticas patrimonialistas que dominavam a gestão do Estado naquele momento.

Esse movimento na direção da implantação de uma administração pública mais eficiente no Brasil sofreu avanços e retrocessos nesses quase cem anos de reformas administrativas, considerando aquela ocorrida no Governo Vargas como a primeira dessas reformas. No período imediatamente posterior ao primeiro Governo de Getúlio Vargas, mas precisamente após 1945, tem-se um retrocesso em vários aspectos da Gestão Pública, principalmente no que diz respeito a uma volta das práticas patrimonialistas de gerir o Estado, expressa, principalmente, na contratação de servidores públicos sem concurso. Já na década de 1960, durante a ditadura militar que governava o país, teve-se a edição do Decreto-Lei 200 de 1967, que propunha uma grande transformação do Estado brasileiro, com a implantação de modernas técnicas administrativas. Algumas dessas técnicas foram realmente implantadas, tais como, diferenciação entre Administração Pública Direta e Indireta, normas de aquisição e contratação de bens e serviços pelo Estado e etc. Mas, também, foi nesse período que aumentou muito a contratação de servidores sem concurso para as empresas estatais e enfraquecimento da Administração Direta com desvalorização dos seus servidores.

Após a ditadura militar, já durante o governo Sarney, período de redemocratização do país, começa uma tentativa de Reforma Administrativa, visando recompor a capacidade gerencial do Estado e adequá-lo aos novos desafios de uma sociedade democrática. Mas essa Reforma não foi para frente, ficando como saldo positivo apenas a criação da Escola Nacional de Administração Pública e a aprovação no Congresso Nacional da lei que criava a carreira de EPPGG, resgatando a proposta formulada pelo Embaixador Rouanet em 1982. 
A constatação que a Administração Pública estava acéfala, sem uma política de reposição dos seus quadros, incapaz de manter uma efetividade da gestão já era conhecida durante a campanha para Presidente da República de 1994. Em 1995, já durante o Governo de Fernando Henrique, foi colocada em curso a Reforma Administrativa, sob a direção do Ministro da Administração e Reforma do Estado, Luiz Carlos Bresser Pereira. Tratava-se de uma reforma ampla, bastante complexa, que envolvia mudanças radicais nas relações do Estado com a sociedade e com seus servidores, além buscar a passagem do modelo burocrático de administrar o Estado para o modelo gerencial. No bojo dessa Reforma estava o objetivo de fortalecer o Núcleo Estratégico do Estado, mas para isso o governo precisava de servidores bem qualificados, aptos a assumir postos de comando dentro da Administração e capazes de assumir novos desafios. A estratégia que o governo usou foi valorizar um grupo de carreiras denominadas Ciclo de Gestão, dentre as quais estava a de EPPGG. Não estava nos planos da Reforma criar uma carreira específica para gerir o Estado, mas a junção de vários fatores fez com que o articulador principal da Reforma, Bresser Pereira, tivesse um contato muito próximo com integrantes da carreira de EPPGG durante a formulação da Reforma. Bresser enxergou nos Gestores o profissional com perfil mais identificado com as novas propostas de gestão do Estado que o Governo pretendia implantar. Mas conhecendo também a situação difícil pela qual passava essa Carreira naquele momento, resolveu, mesmo sem estar previsto na Reforma, reestruturá-la e transformá-la numa ferramenta primordial à consecução do objetivo de fortalecer o Núcleo Estratégico do Estado.

Os concursos para o cargo de EPPGG voltaram a ser realizados paulatinamente a partir de 1996, seus integrantes foram distribuídos por praticamente todos os Órgãos da Administração Direta, participando ativamente de vários projetos de formulação de Política Públicas e ocupando vários cargos dentro do Governo. Em 2003 termina o segundo mandato do Presidente Fernando Henrique Cardoso e começa o Governo do Presidente Lula, os Gestores continuaram sendo contratados e demandados por praticamente todos os órgãos, dando seqüência ao trabalho de articulação entre o pensamento da cúpula do Governo, as áreas executoras das políticas públicas e as demandas da sociedade. A continuação do fortalecimento dessa carreira, e aproveitamento da experiência 
administrativa que seus integrantes traziam do governo anterior, sem dúvidas, facilitou os avanços de algumas Políticas Públicas alcançados no Governo atual.

Diante do que foi exposto, conclui-se que a reestruturação da carreira de Especialistas em Políticas Públicas e Gestão Governamental, iniciada no bojo da Reforma Administrativa de 1995, embora não estivesse prevista em seus objetivos iniciais, foi eficaz como política de fortalecimento do Núcleo Estratégico do Estado. Porque a partir dessa reestruturação a Administração Pública passou a contar com um corpo de servidores de alta qualificação e formação generalista; proporcionando, através da transversalidade e da mobilidade, que são características dessa carreira, uma visão global da administração pública. Que juntamente com a condição de servidores dos quadros permanentes da Administração Direta, garante uma espécie de memória à gestão pública. Evitando a descontinuidade das Políticas Públicas, causada, muitas vezes, pela evasão dos profissionais que realizavam esse trabalho, mas que não pertenciam aos Quadros da Administração, e por isso acabavam indo embora toda vez que ocorria uma mudança de governo.

\subsection{Recomendações para trabalhos futuros}

As reformas da Administração Pública no Brasil são um tema bastante ede suas variáveis. Esse trabalho abordou apenas um dos objetivos, o fortalecimento do Núcleo Estratégico do Estado, de um dos três pilares que compunham a Reforma Administrativa de 1995. Mas, caso pesquisas futuras desejem aprofundar-se nesse mesmo tema, existem muitas perguntas a se responder, por exemplo: 0 fortalecimento do Núcleo Estratégico do Estado refletiu na melhoria da prestação dos Serviços Públicos? O que se pode fazer para levar os avanços ocorridos no Núcleo Estratégico para as outras áreas do Estado? O fortalecimento do Núcleo Estratégico se deu de maneira uniforme em todos os órgãos que compõe a Administração Pública Federal?

A realização desse trabalho não teve, nem por um momento, a pretensão de esgotar a discussão sobre o assunto, mas apenas o desejo detalhá-lo, deixando a questão em aberto para embates futuros. 


\section{REFERÊNCIAS}

BRESSER PEREIRA, L. C. A Reforma Gerencial do Estado de 1995. Revista de Administração Pública 34(4), julho, 2000, Rio de Janeiro (RJ). Disponível em: <http://www.bresserpereira.org.br/view.asp?cod=91> Acesso em 15/11/2010.

. Da Administração Pública Burocrática á Gerencial. Revista do Serviço Público, 47(1), janeiro/abril de 1996, Brasília (DF). Disponível em: <http://www.bresserpereira.org.br/view.asp?cod=87> Acesso em 15/11/2010.

COSTA, F. L. Brasil: 200 anos de Estado; 200 anos de administração pública; 200 anos de reformas. Revista de Administração Pública 42(5)'829-74 set/out. 2008, Rio de Janeiro (RJ). Disponível em: <http://www.scielo.br/pdf/rap/v42n5/a03v42n5.pdf> Acesso em 15/11/2010.

GRAEF, A.; FERNANDES, C. C. C.; SANTOS, L. A. Administrando o Estado. A experiência dos gestores governamentais. Revista do Serviço Público, ano 45, vol. 18, julho/agosto de 1994, Brasília (DF).

MARCONI, M. A; LAKATOS, E. M. Fundamentos de metodologia cientifica. São Paulo: Atlas, 2010.

OLIVEIRA, M. P.; CASSIS, M. R.; CÉSAR, M. A.; EGLER, I. H.; OLIVEIRA, A. S. S. Aprimoramento da Gestão da Carreira do Especialista em Políticas Públicas e Gestão Governamental. Secretaria de Gestão do Ministério do Planejamento Orçamento e Gestão, 2009, disponível em: $<$ http://www.planejamento.gov.br/secretarias/upload/Arquivos/seges/EPPGG/outros/ produto II consolidacao documentos.pdf> Acesso em 15/11/2010.

REZENDE, F. C. Porque falham as reformas administrativas. Rio de Janeiro: FGV, 2004.

ROUANET, S. P. Criação no Brasil de uma Escola Superior de Administração Pública. Brasília: ENAP, 2005.

SANTOS, L. A.; CARDOSO, R. L. S. A experiência dos Gestores Governamentais no Governo Federal do Brasil. V Congresso Internacional do Centro LatinoAmericano de Administração para o Desenvolvimento - CLAD, disponível em:<http://www.planejamento.gov.br/secretarias/upload/Arquivos/seges/EPPGG/doc umentos/artigos/CLAD 2000.pdf> Acesso em 15/11/2010.

ZANELLLA, L. C. H. Metodologia da pesquisa. Florianópolis: SEaD/UFSC, 2006. 


\section{APÊNDICES}

\subsection{Apêndice A - Entrevista Estruturada}

Duração prevista 15 minutos.

Na sua opinião:

1) O governo utilizou a reforma administrativa de 1995 para reestruturar a carreira de Especialista em Políticas Públicas e Gestão Governamental (EPPGG)? Caso afirmativo, qual foi o grau de sucesso da iniciativa?

2) $O$ intuito do governo foi somente de dotar o Núcleo Estratégico com servidores de alta competência, bem treinados e remunerados ou houve outras considerações levantadas pelo Governo? Se houve outras considerações, quais foram elas?

2.1) Como a reestruturação da carreira de EPPGG gerou impacto no fortalecimento do Núcleo Estratégico do Estado?

3) Com relação à reestruturação da carreira de EPPGG, as outras medidas tomadas pelo governo na Reforma Administrativa de 1995, permitiram que a carreira de EPPGG tivesse eficácia como instrumento de fortalecimento do Núcleo Estratégico do Estado? Se não, alguma outra medida poderia ter sido implementada? 


\subsection{Apêndice B - TERMO DE CONSENTIMENTO LIVRE E ESCLARECIDO}

$\mathrm{Eu}$, residente, e

domiciliado(a) ,nascido(a) em , ocupante da função

concordo de livre e espontânea vontade em conceder entrevista presencial respondendo a três questões previamente elaboradas acerca da reestruturação da carreira de Especialista Políticas Públicas e Gestão Governamental, decorrente da Reforma Administrativa do governo federal brasileiro realizada a partir de 1995. Elaboradas pelo aluno do curso de Administração a Distância da Universidade de Brasília, Genivaldo de Freitas Bonfim, matrícula 06/72394, para compor sua monografia.

Ciente do caráter acadêmico do referido trabalho, autorizo a divulgação do conteúdo de minha entrevista, devidamente referenciado, bem como de meu nome, cargo e instituição. Assino o presente documento em duas vias de igual teor e forma, ficando uma em minha posse.

Brasília, de de 2010.

(assinatura do entrevistado)

(Genivaldo de Freitas Bonfim) 


\subsection{Apêndice C - Entrevista: Maria da Penha B. da Cruz - Coordenadora-Geral da Gestão da Carreira de EPPGG do Ministério do Planej. Orçamento e Gestão.}

1) Antes de responder à pergunta vou falar um pouco da criação da Carreira de EPPGG, que aconteceu em 1989, durante o processo de redemocratização do país, quando a Administração Pública não contava com quadro de servidores preparados para formulação de políticas públicas.

Essas políticas eram formuladas dentro de outro desenho, através dos Planos de Desenvolvimento, onde a formulação das políticas era feita noutra instância, pessoas vindas de fora da Administração Direta, normalmente empregados públicos, o pessoal das estatais, que eram os grupos mais fortes dentro da administração. Essas políticas eram formuladas de cima para baixo, sem a participação da sociedade.

Com a redemocratização do país essa formulação de políticas públicas ganha outro desenho, envolve outros atores, conta com a participação dos setores organizados da sociedade civil. Isso exigia um novo corpo funcional, mais preparado, capaz de fazer a articulação entre a parte política, técnica e executora da administração pública e a sociedade. Para formar esse novo corpo de servidores a inspiração foi o modelo francês, com sua escola de governo; então, cria-se em 1989 a Carreira de EPPGG, mas a primeira turma só tomou posse em 1990. Depois dessa primeira turma o segundo concurso só ocorreu em 1996, nesse intervalo o projeto foi deixado de lado, a carreira quase foi extinta, sendo transformada em outra, depois voltando à condição original. Mas a partir de 1996 a valorização dessa carreira entra na agenda política do governo, com a realização de concursos regulares e preenchimento das vagas previstas na sua criação. Juntamente com outras carreiras que passaram a integrar o chamado Ciclo de Gestão, todas elas passaram a ser fortalecidas a partir da Reforma de 1995.

2) O que consigo captar dessa época é que havia a intenção, por parte do governo, de criar um corpo funcional permanente capaz de fazer a articulação entre a instância política, a parte executora da administração e a sociedade. O diferencial dessa carreira era o seu aspecto generalista e a sua mobilidade, onde o profissional 
ficava um período num Ministério, depois ia para outro, proporcionando-lhe uma visão geral da administração. Essa visão do Gestor complementava a visão mais específica e técnica dos especialistas de outras carreiras, com quem ele trabalhava na formulação das políticas públicas. O Gestor por si só não mudava a administração, mas ele obteve sucesso no seu trabalho porque compôs uma força maior que fazia parte do Núcleo Estratégico do Estado, que foi fortalecido na Reforma Administrativa de 1995.

2.1) É uma questão difícil de ser mensurada, é uma avaliação muito subjetiva. Hoje temos 888 Gestores ativos e mais de $60 \%$ desses profissionais ocupam cargos em comissão. Esses servidores espalhados por diversos órgãos em diferentes níveis de funções, com certeza, colaboraram para uma remodelagem da administração que vem acontecendo desde a Reforma de 1995. A atuação desses profissionais foi mais um fator positivo na engrenagem de toda uma mudança decorrente da redemocratização do país, e o Gestor é uma peça importante dessa engrenagem. Mas, agora, é difícil de mensurar essa contribuição, o que houve foi uma grande mudança na administração e o trabalho dos gestores tem a ver com isso. A partir da reestruturação da carreira de EPPGG a administração passou a contar com um corpo técnico permanente que tem visão da formulação de políticas públicas e visão da nova maneira de gerir o Estado, que tem uma contribuição efetiva a dar ao Estado, então esse foi o grande impacto que a carreira gerou.

3) Entrevistada pergunta: quais as outras medidas que você está pensando que poderiam ter essa eficácia? Entrevistador responde: caso você ache que as medidas tomadas pelo Governo para reestruturar a carreira foram suficientes para que ela se tornasse eficaz como instrumento de fortalecimento do Núcleo Estratégico, tudo bem, mas se achar que o Governo poderia ter tomado outras medidas pode citá-las. Maria da Penha - Sim, além da reestruturação da carreira outras medidas que foram tomadas pelo governo também ajudaram a implementar a Reforma. Por exemplo, as alterações na Lei 8112/90, colocando fim a alguns privilégios e a Reforma da Previdência foram necessárias naquele contexto. Agora eu acredito que a idéia pensada pelo Governo naquela época para a carreira de Gestores era a seguinte: um grupo com uma missão específica para atuar numa área específica. Compondo com os outros servidores dos órgãos onde atuariam e 
com os atores sociais envolvidos no processo. Nesse aspecto eu entendo que as medidas foram bem sucedidas; mas na prática, esse sucesso não foi uniforme, varia de Ministério para Ministério. Mas, isso está mais ligado às prioridades de governo, no governo Lula, por exemplo, a área social avançou muito e o trabalho dos Gestores foi fundamental para isso. Mas, em alguns Ministérios, devido às condições particulares do órgão, não tiveram a oportunidade de ver a importância do trabalho dos gestores. Mas, de modo geral, as medidas obtiveram sucesso. 


\subsection{Apêndice D - Entrevista: Sandro E. M. de Alencar - Coordenador da Coordenação-Geral da Gestão da Carreira de EPPGG do Ministério do Planej. Orçamento e Gestão.}

1) A carreira de EPPGG foi beneficiada sim pela Reforma. Não era o foco dela, mas no bojo da valorização das carreiras do Ciclo de Gestão ela foi beneficiada. A prova de que isso aconteceu foi a retomada dos concursos para Gestor a partir de 1996, mas isso não ocorreu de forma isolada, junto com os EPPGGs outras carreiras, tais como, CGU, IPEA, e outras também foram valorizadas a partir daquela Reforma. Mas, de fato, o Governo usou aquele momento para dar uma revitalização na carreira de EPPGG.

2) O treinamento de alta competência, de alguma forma, já vinha sendo feito dentro da administração. Toda vez que o governo precisava ele montava uma estrutura de forma insulada, corpos paralelos para desenvolver trabalhos mais complexos, mas depois esses corpos se perdiam. Portanto, o fortalecimento dessa carreira, além de trazer servidores de alta qualificação para dentro da administração criou uma memória permanente da administração. Também através desses profissionais abriu-se na administração um canal de comunicação entre a alta administração, os servidores de linha e a sociedade. Outra vantagem foi a transversalidade dessa carreira, capaz de povoar a administração em todos os graus de hierarquia; tem-se hoje, Gestor exercendo cargos em nível estritamente burocrático, apesar de ser uma disfunção da carreira, e Gestor em cargos da alta assessoria e decisão, como Chefes de Gabinetes de Ministros e Secretários de Governo. Traduzindo as palavras dos atores envolvidos no processo para a linguagem da formulação de políticas públicas.

2.1) O Núcleo Estratégico do Estado foi beneficiado com a criação de uma memória da administração, como eu falei antes, hoje os governos saem e as informações ficam, podendo o governo seguinte retomar políticas que estavam dando certo. A criação de uma rede capaz de trazer o que está acontecendo em cada órgão para subsidiar a formulação de políticas públicas. 
3) Sim, as medidas permitiram que não só os EPPGGs, mas todo o Ciclo de Gestão fosse eficaz nesse fortalecimento. A atuação do Governo tornou-se mais efetiva, com retomada da capacidade de gestão. Mas houve obstáculos em determinadas áreas, a reforma avançou numas áreas noutras não. Hoje temos um descompasso entre formulação e execução das políticas. Ministérios como a Fazenda, Orçamento e Gestão e outros, digamos assim, responsáveis por pensar as políticas de forma estratégica, estão muito bem, com elevada capacidade técnica. Mas na hora de transformas as idéias geradas nesses Ministérios em prestação de serviços efetivos, Ministérios como: Cidades, Integração e outros, mais ligados à execução, aí temos um descompasso. Lá tem problemas de execução, planejamento, controle, enfim em todas as funções da administração. Mas isso não é um problema da Reforma, é uma questão incremental, primeiro era necessário fortalecer o Núcleo Estratégico, como foi. Mas na hora de levar a prestação de serviços para a sociedade, isso foi interrompido, para o mal ou para o bem, não estou fazendo juízo de valor, mas foi o que aconteceu. Hoje estamos nesse impasse, quem vai prestar o serviço? É o Estado? De que forma? Diretamente ou de forma indireta. Caso seja de forma direta, temos que acertar muita coisa, porque têm setores da administração que estão no século XXI, mas há setores que estão no século XX ou mesmo no século XIX em termos de qualidade na prestação de serviços públicos. Hoje o Estado tem mais dinheiro, mais capacidade de gestão, mas está travado na execução. Precisamos acertar o passo entre formulação, execução e controle. Não podemos pensar que uma Reforma Gerencial vai ser uma panacéia que resolverá todos os problemas da administração, alguns setores da administração precisam primeiro chegar ao modelo Weberiano, para depois dar um passo além.

Finalizando, a reestruturação da carreira de Gestores trouxe eficácia para o fortalecimento do Núcleo Estratégico. Não apenas a carreira de EPPGG, mas todas as outras carreiras do Ciclo de Gestão que passaram a ser mais valorizadas a partir da Reforma de 1995. Mas a carreira de Gestores vai, sim, ser mais eficaz quando resolvermos o descompasso entre formulação e execução de políticas públicas. 


\subsection{Apêndice E - Entrevista: Ciro C. C. Fernandes - Diretor de Articulação e Inovação Institucional do Ministério do Planej. Orçamento e Gestão.}

1) A Reforma Administrativa de 1995 não previa a criação de uma carreira específica para gerir a administração, mas no início do trabalho de formulação da Reforma, ao tomar conhecimento da existência da carreira de Gestores, o Ministro Bresser Pereira entendeu que valia a pena retomar essa carreira; que foi criada em 1989, fez o primeiro concurso e depois ficou parada. O que houve foi um encontro da formulação da Reforma com a existência da carreira que acabou sendo proveitoso para ambos.

2) A questão central era o fortalecimento do Núcleo Estratégico. $\mathrm{Na}$ concepção da Reforma Administrativa de 1995 tinha-se que fortalecer o Núcleo Estratégico porque o Estado estava desmantelado na sua capacidade de gestão, havia um desmantelamento do cérebro do Estado, o Estado estava acéfalo.

A Reforma previa um fortalecimento do Núcleo Estratégico e uma descentralização da execução dos serviços para as agências executivas e as organizações sociais. Nesse desenho de fazer uma ampla descentralização das atividades do estado, você tinha que fortalecer o Núcleo Estratégico, deixá-lo mais qualificado tecnicamente, para poder gerir esse processo de descentralização. Paradoxalmente, para ter um Estado mais leve tinha-se que fortalecer o seu Núcleo Estratégico. A motivação principal era essa e paralelamente tinha a discussão sobre a valorização das carreiras que já vinha acontecendo dentro do governo desde a Constituição de 1988; havia também a discussão de como inserir os Gestores no novo desenho da administração pública.

2.1) O principal impacto foi que as características da carreira, perfil generalista, mobilidade, transversalidade e a alta qualificação, possibilitaram a distribuição dos Gestores por diversos órgãos da Administração. Havia uma grande carência de profissionais com essa capacidade; a chegada dos Gestores foi como gotas de água num solo que há muito sofria com uma seca; onde essas gotas pingaram houve germinação de alguma coisa. Esse era o contexto da época, uma 
enorme carência de pessoas qualificadas no Estado brasileiro. Então eu diria que o impacto da carreira se deveu a essa carência e às características da carreira.

3) Não acho que a carreira foi bem eficaz no processo de fortalecimento do Núcleo Estratégico do Estado, porque essa reestruturação não pode ser pensada como um processo que se encerrou; a retomada da carreira a partir de 1996 foi muito importante para Reforma. Porém a Reforma Administrativa de 1995 avançou muito pouco nos outros aspectos que precisavam ser enfrentados para fortalecer 0 Núcleo Estratégico. Pelo contexto político da época, pelas dificuldades enfrentadas não foi possível fazer a ampla reestruturação dos Ministérios e Secretárias, como era previsto. Essa reestruturação melhoraria 0 acompanhamento da descentralização dos serviços que corria noutro eixo da Reforma. Nesse desenho onde o fortalecimento do Núcleo Estratégico acompanharia o processo de descentralização, houve poucos avanços. Até porque era difícil fazer um redesenho do Estado nas proporções imaginadas, com as limitações técnicas e políticas da época. Nesse aspecto o aproveitamento dos Gestores foi muito bom, o impacto da carreira foi muito grande, mas o grande redesenho do Estado não se realizou, ele ainda estar por acontecer, pode levar décadas.

Desta maneira o fortalecimento do Núcleo Estratégico é algo que ainda não se completou, é necessário se completar. Essa agenda ainda é importante, inclusive com a continuação do recrutamento de Gestores. Pode-se dizer que o impacto ainda vai continuar acontecendo ao longo dos anos, independente de quem será Governo. 